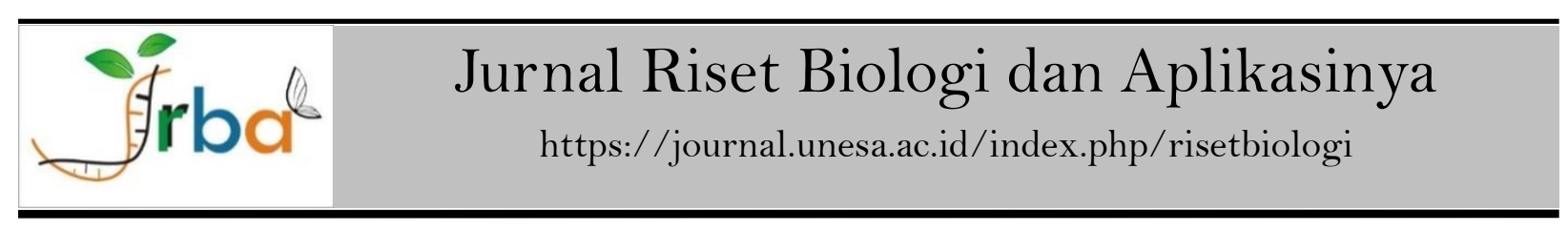

\title{
The First Investigation of Microplastics Contamination in Estuarine Located in Puger District, Jember Regency, Indonesia
}

\author{
Selvi Ariyunita ${ }^{1 *}$, Yeny Dhokhikah', Wachju Subchan ${ }^{3}$ \\ ${ }_{1,3}$ Biology Education Study Program, Faculty of Teacher Training and Education, University of Jember \\ Jln. Kalimantan No. 37, Kampus Tegalboto, Sumbersari, Jember District, East Java 68121, Indonesia \\ ${ }^{2}$ Environmental Engineering, Faculty of Engineering, University of Jember, Kampus Tegalboto \\ Jln. Kalimantan No. 37, Kampus Tegalboto, Sumbersari, Jember District, East Java 68121, Indonesia \\ *Corresponding Author: \\ e-mail: selvi.ariyunita@unej.ac.id
}

\section{Article History \\ Received : 10 February 2021 \\ Revised : 21 February 2021 \\ Approved : 22 March 2021 \\ Published : 31 March 2021}

\section{Keywords}

Microplastics; pollution; characterization; contamination; estuarine

\begin{abstract}
Microplastics are harmful to the ecosystem and need to solve immediately. Detection of microplastic contamination is the first step to reduce plastics pollution. Estuarine in Puger has a high potential for microplastic pollution related to the multifunction of waters as ports, tourism, fish market, fish processing, and human settlements. However, there are no studies related to microplastic contamination in the area. The objectives of this research were to determine microplastic contamination in the estuarine located in Puger District, Jember Regency, Indonesia. The research results were the first evidence to inform the society and local government about the actual condition of plastic pollution, especially in the aquatic ecosystem. The sampling sites were determined by purposive sampling. Fifty liters of water from each station (with three repetitions) were taken using a $24 \mathrm{~V}$ water pump and then filtered using stainless steel filter (mesh $5 \mathrm{~mm}$ and $0.2 \mathrm{~mm}$ ). The filtered samples were placed in a sterile bottle sample, stored at $4 \pm 2^{\circ} \mathrm{C}$. Microplastics were counted and categorized according to size, color, and type under a microscope stereo. Microplastic abundance was calculated based on the number of microplastic particles identified per liter of sample water (particle/liter). The result showed that the study area was contaminated by microplastics throughout site sampling, with abundances varying from 0.03 particles/liter to 0.19 particles/liter. The highest microplastic abundance found near the fishery market. The microplastics also vary in size, color, and type. According to characterization, the sources of microplastic contamination come from human-based activities.
\end{abstract}

How to cite: Ariyunita, S., Dhokhikah, Y., \& Subchan, W. (2021). The First Investigation of Microplastics Contamination in Estuarine Located in Puger District, Jember Regency, Indonesia. Jurnal Riset Biologi dan Aplikasinya, 3(1): 7-12. DOI: https://doi.org/10.26740/jrba.v3n1.p7-12.

\section{INTRODUCTION}

Sustainability of the marine ecosystem is one of the purposes of Sustainable Development Goals. A massive problem in the marine ecosystem nowadays is plastic debris contamination from land-based activities and marine-based activities (Clark et al., 2016). Plastic is a persistent pollutant in the environment. It needs a long time to break down into smaller sizes, reaching micro and nanometer (Wagner \& Lambert, 2018; GESAMP Joint Group of Experts on the Scientific Aspects of Marine Environmental Protection, 2016). Its persistent and buoyant properties contributed to widespread microplastics in the marine ecosystem $(\mathrm{Ng} \&$ Obbard, 2006).

Microplastics are plastic with $0.02 \mathrm{~mm}-5 \mathrm{~mm}$ size. Microplastics are harmful in the environment because it is difficult to degrade, so this particles accumulate in water bodies, sediments, and organisms to the food chain and end up with humans as top predators in the food chain (Jabeen et al., 2017; Wagner \& Lambert, 2018). Microplastics in organisms cause a direct effect as irritation to the digestive tract and cause physiological disruptions (Brennecke et al., 2015; Franzellitti et al., 2019). 
Many studies reported that plastic debris contamination, particularly microplastic occurs in estuarine and coastal in Indonesia (Joesidawati, 2018; Ayuningtyas, 2019; Cordova et al., 2019; Cordova \& Hernawan, 2018; Taryono et al., 2020). Estuarine is a potential area that accumulates plastic debris from land-based sources along river streams and becomes marine ecosystem pollutants (Zhao et al., 2014; Kurniawan \& Imron, 2019). Bauer-civiello et al. (2019) also clarify that mismanage waste from urban area contribute the input of plastic debris in the environment. It means that areas surrounded by the density of population activitis have more significant potential in contaminating microplastics because of plastic product use (Widianarko \& Hantoro, 2018). This condition can alter the sustainability of the estuary and marine ecosystem. Moreover, it can decrease ecosystem productivity.

The adverse effect that occurs from the widespread microplastic pollution needs to solve immediately. In this case, detecting microplastic contamination is an urgent step to reduce pollution (Xu et al., 2018). Although many researchers reported contamination of microplastic in Indonesia, there are no reports related to microplastic pollution studies in the estuarine along Puger Coastal, Jember Regency. The Puger Coastal has a high potential for microplastic pollution because of its multifunctional designation of waters as ports, tourism, fishery market place, fish processing industry, and residential areas. Moreover, two estuaries (such as Bedadung and Getem estuary) are critical areas for accumulating various pollutants from land-based activities (Wagner \& Lambert, 2018; Xu et al., 2018; Maherlsa et al., 2019).

This research aimed to determine and characterize microplastic contamination in the estuarine along Puger coastal, Jember Regency. The research results were the first evidence that inform the society and local government about the actual condition of plastic pollution, especially in the aquatic ecosystem. Moreover, it hopefully can be used to improve the policy of waste management in Jember Regency.

\section{MATERIALS AND METHODS}

\section{Study area}

The sampling site of this research was the estuarian on the Puger Coastal, Jember Regency (Figure 1). Determination of sampling sites based on purposive sampling adjusted to the designation of waters, including 1). Near Tambak (near the shrimp pond), latitude: -8,277069 and longitude: 113,540783; 2). Estuary Getem, latitude: -8,384666 and longitude: 113,411809; 3). Estuary Bedadung /Pelawangan, Latitude: -8,382126 and longitude: 113,472933; 4). Tempat Pelelangan Ikan (TPI)/ Fishery market, latitude: $\mathbf{- 8 . 3 7 9 2 7 2}$ and longitude: 113,476113 . The study was conducted from October 2019 until February 2020.

\section{Sampling Methods}

Fifty liters of water from each station were taken (with three repetitions) using 24 Volt water pumping. The sample was then filtered using a stainless steel filter with a mesh stack (size $5 \mathrm{~mm}$ and $0,2 \mathrm{~mm}$ ). The filtered samples were placed in bottle samples and stored at $4^{\circ} \mathrm{C} \pm 2^{\circ} \mathrm{C}$. The equipment was rinsed first with $\mathrm{ddH}_{2} \mathrm{O}$ to avoid contamination.

\section{Sample Preparation}

The samples were transferred to the Erlenmeyer tube and dried in the oven at $80-90^{\circ} \mathrm{C}$ for 24 hours. Then added $5 \mathrm{~mL}$ of $30 \%$ hydrogen peroxide $\left(\mathrm{H}_{2} \mathrm{O}_{2}\right)$ and heated in a water bath at $80^{\circ} \mathrm{C}$ for 24-48 hours. Hydrogen peroxide is the destruction solution to degrade the organic material (Cordova et al., 2019).

\section{Microplastics characterization}

Microplastics were identified under microscope stereo by particle size $0.2-5 \mathrm{~mm}$, unsegmented, and unbranched structure. Based on the color, microplastics were categorized as black, transparent, and colored. Furthermore, based on the shape, microplastics were categorized as fibers, granules, fragments, and foam (Cordova et al., 2019).

\section{Data Analysis}

Microplastic abundance was calculated based on the number of microplastic particles identified per liter of sample water (particle/liter).

\section{RESULTS AND DISCUSSION}

\section{Abundance of microplastic in the study area}

The results showed that microplastics contaminated all sampling sites in the study area. The highest microplastic abundance was 0.19 particles/liter, as observed at station 4 (estuarine near fishery market). The lowest microplastic abundance was found at station 3 (Bedadung estuarine) with 0.03 particles/liter (Figure 2). 


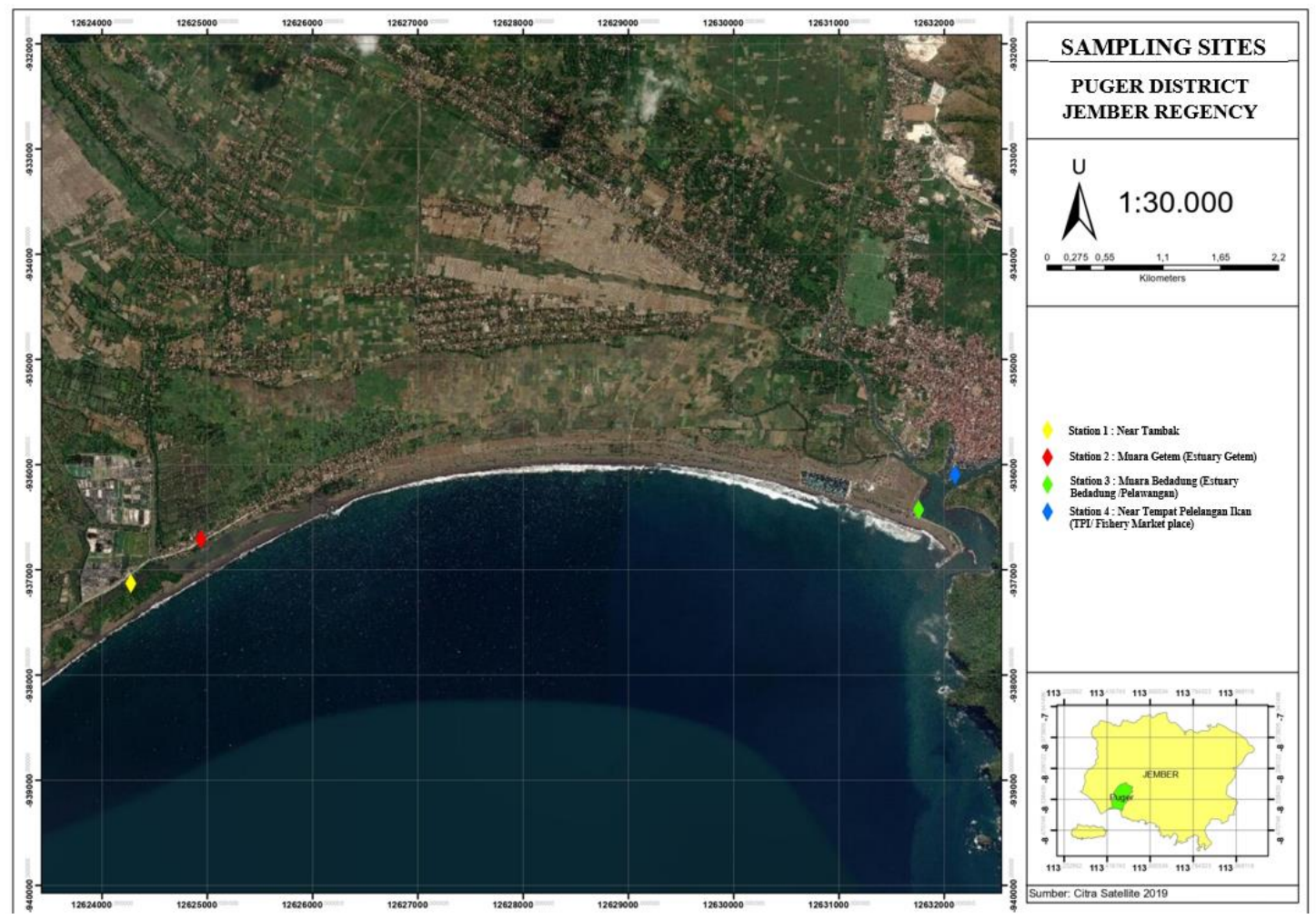

Figure 1. Study area of Puger District, Jember Regency, Indonesia

Types, sizes, and colors of microplastics

Besides the abundance, microplastics were also characterized into sizes, types, and colors (Figure 3 and 4). This characterization is helpful to determine the source of microplastic contamination. The results showed that the identified microplastics were fragments (77.42\%) and fiber (22.58\%). According to Ayuningtyas (2019), microplastic fragment type was more abundant than fiber. The sources of the fragment derived from pieces of pipes, plastic bottles, and plastic bags. In comparison, the type of fiber derived from synthetic fabrics, ship waste fishermen, and fishing gear such as fishing nets and fishing lines.
The size range of microplastic determines the potential effect of microplastics in the ecosystem, especially in the organism (Zhao et al., 2014). In this study, $40 \%$ of the total identified microplastics were between 1-5 $\mathrm{mm}$ in size. Furthermore, 33\% and $27 \%$ were respectively for $0.3-0.5 \mathrm{~mm}$ and $0.5-1$ $\mathrm{mm}$. The high abundance of microplastics in this size range $(1-5 \mathrm{~mm})$ indicates that microplastic particles have not been degraded for a long time (Cordova et al., 2019). Some factors that affected microplastic sizes' distribution are hydrodynamic condition, wind speed, and bio-fouling (Afdal et al., 2019).

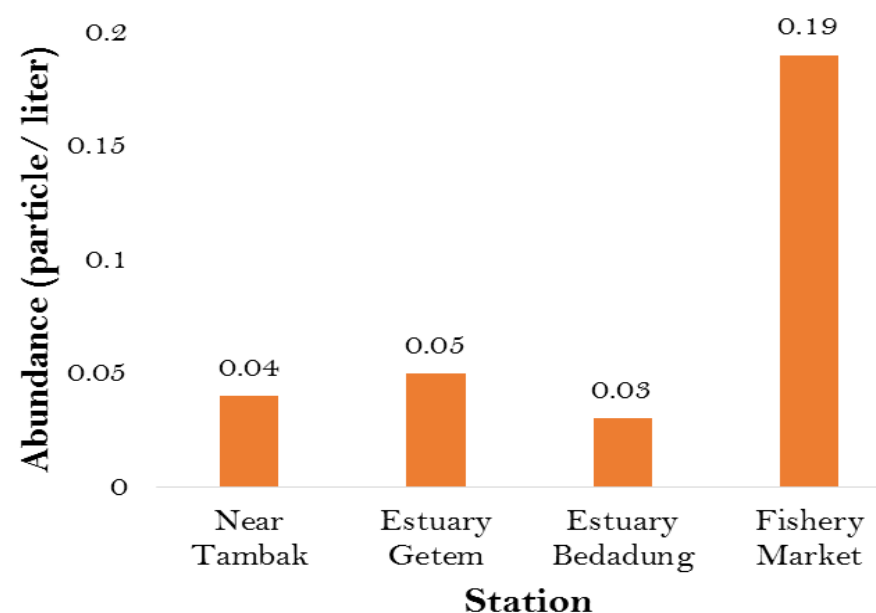

Figure 2. Abundance of microplastic in the study area 
Types

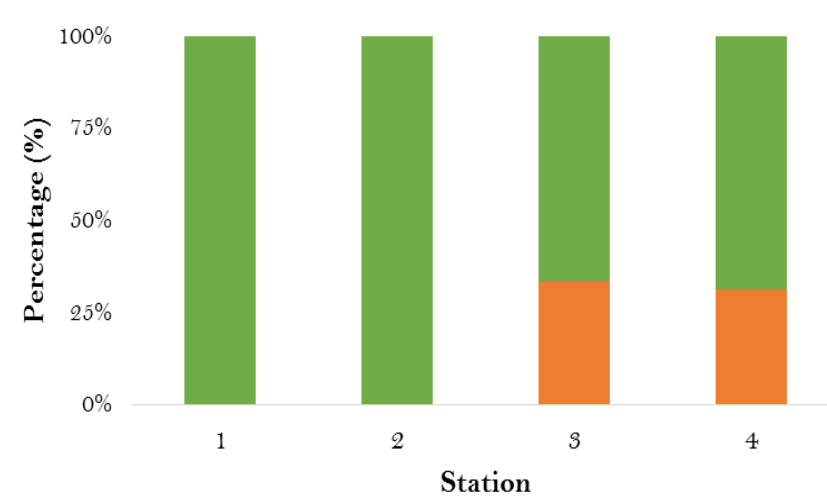

$\square$ Fiber $\square$ Granule $\backsim$ Fragment
Sizes

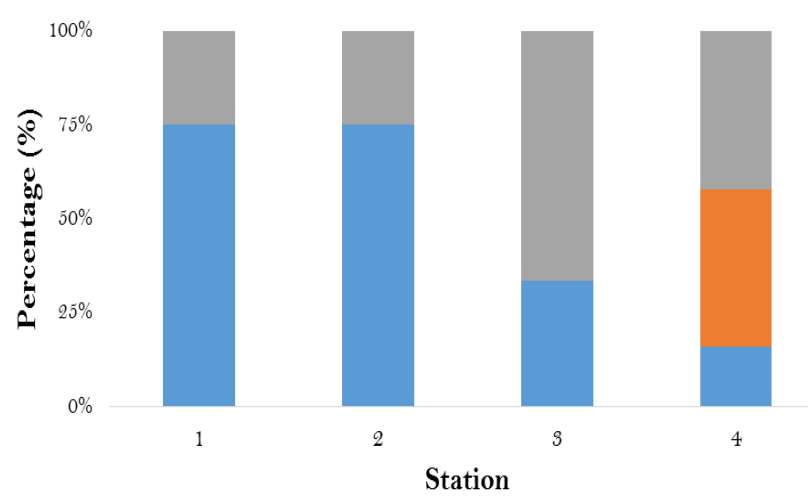

$\square 0,3-0,5(\mathrm{~mm}) \quad \square, 5-1(\mathrm{~mm}) \quad \square 1-5(\mathrm{~mm})$

\section{Colors}

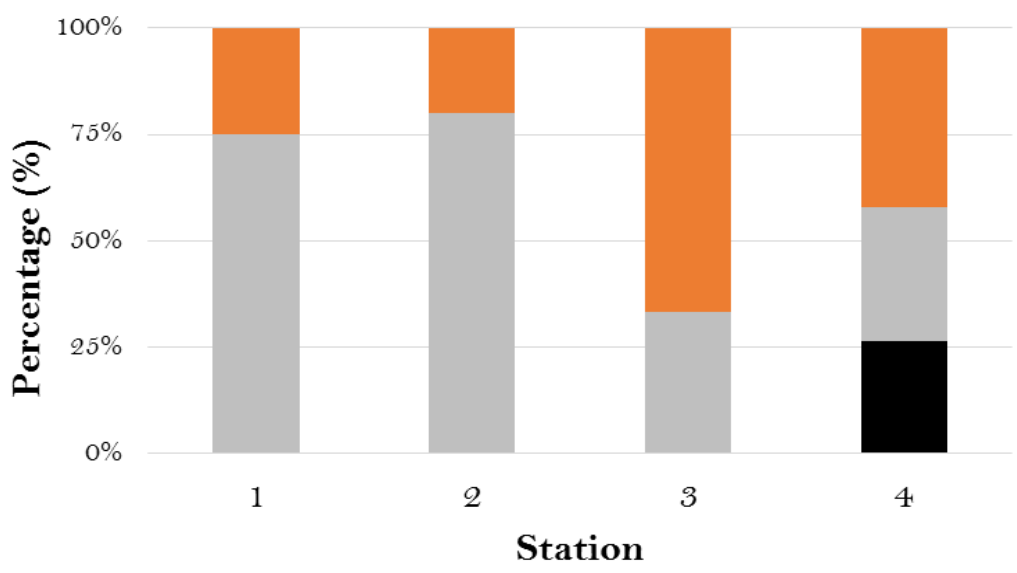

- Black $\square$ Transparent $\backsim$ Color

Figure 3. Microplastics characterization based on sizes, types, and colors in each station 1. Near Tambak; 2. Estuary Getem; 3. Estuary Bedadung; 4. Fishery Market

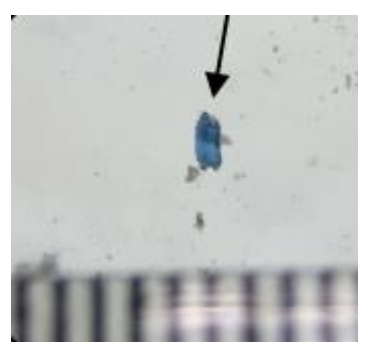

(a)

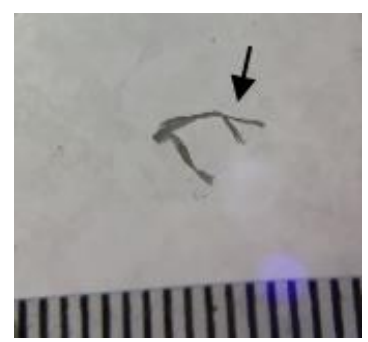

(b)

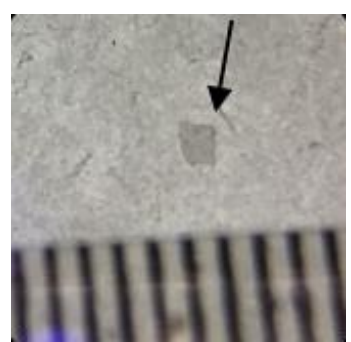

(c)

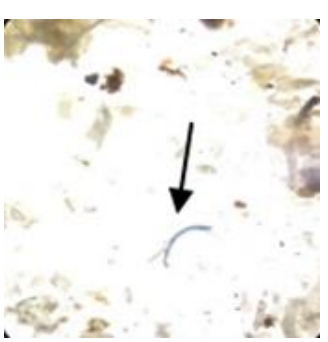

(d)

Figure 4. Identified microplastics under microscope stereo: (a) 0,5-1 mm; Fragment, color; (b) 0.5-1 mm, Fiber, color; (c) 0.5-1 mm; Fragment, transparent; (d) 0.3-0.5 mm; Fiber, Color 
Based on the colors, the identified microplastics were dominated as transparent (45\%), colored (39\%), and black (16\%). Domination of transparent and colored microplastic indicated that contamination sources probably come from human activities, such as plastic, packaging, clothing, and fishing (Zhao et al., 2014). Moreover, the transparent color is harmful and increases the potential for accidentally being eaten because it is hard to distinguish. Various colors, sizes, and shapes of plastic fragments similar to natural food resources and alter the potential of this contaminant ingested by the aquatic organism (Foekema et al., 2013).

Microplastic contamination in this study comes from human-based activities that enter the plastic debris in water bodies. The results support the fact that Asian rivers transport more plastics toward the ocean (van Calcar \& van Emmerik, 2019). Moreover, microplastic availability in estuarine located in Puger District, Jember Regency, can interfere aquatic ecosystem and contribute as a pollutant to the Indian Ocean. The limited research about plastic debris pollution in Jember Regency needs further research about bioavailability and microplastic risk in organisms and ecosystems.

\section{CONCLUSION}

This study reported the first evidence that microplastics contaminate estuarine along Puger coastal. The highest microplastic abundance was 0.19 particles/liter at near fishery market, followed by near Tambak and Estuarine Getem. The lowest microplastic abundance was found at Bedadung Estuarine with 0.03 particles/liter. According to sizes, types, and colors, the identified microplastics were respectively between 1-5 mm (40\%), 0.3-0.5 $\mathrm{mm}(33 \%)$, and $0.5-1 \mathrm{~mm}(27 \%)$; fragments $(77.42 \%)$ and fiber (22.58\%); transparent (45\%), colored (39\%), and black (16\%).

This study provides the first evidence that microplastic contaminate the aquatic ecosystem in Jember Regency. The data also provide information for the society to reduce plastic waste from the sources and the local government as a basic consideration to improve waste management policy.

\section{ACKNOWLEDGMENT}

The author is grateful for full support and funding from PNBP Lembaga Penelitian dan
Pengabdian Masyarakat (LP2M) University of Jember.

\section{REFERENCES}

Afdal, M., Werorilangi, S., Faizal, A., \& Tahir, A. (2019). Studies on Microplastics Morphology Characteristics in the Coastal Water of Makassar City, South Sulawesi, Indonesia. International Journal of Environment, Agriculture and Biotechnology, 4(4), 10281033. https://doi.org/10.22161/ijeab.442 1

Ayuningtyas, W. C. (2019). Kelimpahan Mikroplastik Pada Perairan Di Banyuurip, Gresik, Jawa Timur. JFMRJournal of Fisheries and Marine Research, 3(1), 41-45. https://doi.org/10.21776/ub.jfmr.2019.003.01.5

Bauer-civiello, A., Critchell, K., Hoogenboom, M., \& Hamann, M. (2019). Input of plastic debris in an urban tropical river system. Marine Pollution Bulletin, 144(February), 235-242. https://doi.org/10.1016/j.marpolbul.2019.04.070

Brennecke, D., Ferreira, E. C., Costa, T. M. M., Appel, D., da Gama, B. A. P., \& Lenz, M. (2015). Ingested microplastics $(>100 \mu \mathrm{m})$ are translocated to organs of the tropical fiddler crab Uca rapax. Marine Pollution Bulletin, 96(1-2), 491-495. https://doi.org/10.1016/j.marpolbul.2015.05.001

Clark, J. R., Cole, M., Lindeque, P. K., Fileman, E., Blackford, J., Lewis, C., Lenton, T. M., \& Galloway, T. S. (2016). Marine microplastic debris: a targeted plan for understanding and quantifying interactions with marine life. Frontiers in Ecology and the Environment, $\quad 14(6), \quad 317-324$. https://doi.org/10.1002/fee.1297

Cordova, M. R., \& Hernawan, U. E. (2018). Microplastics in Sumba waters, East Nusa Tenggara. IOP Conference Series: Earth and Environmental Science, 162(1). https://doi.org/10.1088/1755-1315/162/1/012023

Cordova, Muhammad Reza, Purwiyanto, A. I. S., \& Suteja, Y. (2019). Abundance and characteristics of microplastics in the northern coastal waters of Surabaya, Indonesia. Marine Pollution Bulletin, 142(March), 183-188. https://doi.org/10.1016/j.marpolbul.2019.03.040

Foekema, E. M., Gruijter, C. De, Mergia, M. T., Franeker, J. A. Van, Murk, A. J., \& Koelmans, A. A. (2013). Foekema EM. Plastic in North Sea Fish. ES\&T 2013. Environmenrtal Science \& Technology, 47, 8818-8824.

Franzellitti, S., Canesi, L., Auguste, M., Wathsala, R. H. G. R., \& Fabbri, E. (2019). Microplastic exposure and effects in aquatic organisms: A physiological perspective. Environmental Toxicology and Pharmacology, 68(March), $\quad 37-51$. https://doi.org/10.1016/j.etap.2019.03.009

GESAMP Joint Group of Experts on the Scientific Aspects of Marine Environmental Protection. (2016). Sources, fate and effects of microplastics in the marine environment: part 2 of a global assessment. (IMO, $\mathrm{FAO} /$ UNESCOIOC/UNIDO/WMO/IAEA/UN/UNEP/UNDP). In: Kershaw, P.J. (Ed.), Rep. Stud. GESAMP No. 90 
(96 pp). Reports and Studies GESAMP, No. 93, 96 P., 93.

Jabeen, K., Su, L., Li, J., Yang, D., Tong, C., Mu, J., \& Shi, H. (2017). Microplastics and mesoplastics in fish from coastal and fresh waters of China. Environmental Pollution, 221 , 141-149. https://doi.org/10.1016/j.envpol.2016.11.055

Joesidawati, M. I. (2018). Pencemaran mikroplastik di sepanjang pantai kabupaten Tuban. Seminar Nasional Hasil Penelitian Dan Pengabdian Masyarakat 3, September, 7-15.

Kurniawan, S. B., \& Imron, M. F. (2019). Environmental Technology \& Innovation Seasonal variation of plastic debris accumulation in the estuary of Wonorejo River, Surabaya , Indonesia. Environmental Technology \&० Innovation, $16, \quad 100490$. https://doi.org/10.1016/j.eti.2019.100490

Maherlsa, R., Purwiyanto, A. I. S., Agustriani, F., Putri, W. A. E., Fauziyah, \& Ferdiansyah. (2019). Identification of surface macro debrisin river flow and estuary of Musi River, South Sumatera Province, Indonesia. Journal of Physics: Conference Series, 1282(1). https://doi.org/10.1088/1742-6596/1282/1/012106

Ng, K. L., \& Obbard, J. P. (2006). Prevalence of microplastics in Singapore's coastal marine environment. Marine Pollution Bulletin, 52(7), 761-767. https://doi.org/10.1016/j.marpolbul.2005.11.017
Taryono, Pe, E. O. L., Wardiatno, Y., \& Mashar, A. (2020). Macroplastic distribution, abundance, and composition which flows to Cimandiri estuary, West Java. IOP Conference Series: Earth and Environmental Science, 420(1). https://doi.org/10.1088/17551315/420/1/012031

van Calcar, C. J., \& van Emmerik, T. H. M. (2019). Abundance of plastic debris across European and Asian rivers. Environmental Research Letters, 14(12), 124051. https://doi.org/10.1088/1748-9326/ab5468

Wagner, M., \& Lambert, S. (2018). Freshwater Microplastics The Handbook of Environmental Chemistry 58. https://doi.org/10.1007/978-3-319-61615-5

Widianarko, B., \& Hantoro, I. (2018). Mikroplastik Mikroplastik dalam Seafood Seafood dari Pantai Utara Jawa. Available at www.unika.ac.id

Xu, P., Peng, G., Su, L., Gao, Y., Gao, L., \& Li, D. (2018). Microplastic risk assessment in surface waters: A case study in the Changjiang Estuary, China. Marine Pollution Bulletin, 133(June), 647-654. https://doi.org/10.1016/j.marpolbul.2018.06.020

Zhao, S., Zhu, L., Wang, T., \& Li, D. (2014). Suspended microplastics in the surface water of the Yangtze Estuary System, China: First observations on occurrence, distribution. Marine Pollution Bulletin, 86(1-2), 562-568. https://doi.org/10.1016/j.marpolbul.2014.06.032. 